\title{
Resource Use Efficiency in Production of Dry Chilli in Guntur District of Andhra Pradesh, India
}

\author{
Y. Ramana Kumari* and Sunil Nahatkar \\ Department of Agricultural Economics and Farm Management, College of Agriculture, \\ Jawaharlal Nehru Krishi Vishwa Vidyalaya, Jabalpur, India \\ *Corresponding author
}

\section{A B S T R A C T}

K e y w o r d s
$\begin{aligned} & \text { Chilli, Input cost, } \\ & \text { output price, } \\ & \text { Profit, Resource use } \\ & \text { efficiency }\end{aligned}$
Article Info
$\begin{aligned} & \text { Accepted: } \\ & \text { 20 December } 2020 \\ & \text { Available Online: } \\ & \text { 10 January 2021 }\end{aligned}$

Keywords

Chilli, Input cost, output price, Profit, Resource use 10 January 2021
An attempt has been made to examine the resource use efficiency in dry chilli production in Guntur district of Andhra Pradesh. Research was based on randomly selected 99 chilli growers who belong to 3 villages of Guntur district, Andhra Pradesh. The results revealed that cost of seed, manure and fertilizer and price of chilli were significantly affecting profit. On the other hand cost of plant protection chemical was moderately affecting profit. Human labour and fixed cost were insignificant but positively influencing the profit. Bullock labour and machine labour (power use) was negatively significant at one percent level indicating that the farmers incurred more cost on power use and over utilized it. $\mathrm{R}^{2}$ was 0.96 indicates that 96 per cent variation in profit was explained by those variables which were included in the function representing a goodness in fitting the regression equation. The over utilized resource (power use) was found to be 63 per cent, and therefore the study recommended that if the farmers use the bullock and machine power $\left(\mathrm{X}_{5}\right.$ variable) efficiently by 37 per cent more than they could save Rs 11628.00 per hectare (Rs 204 per hour).

\section{Introduction}

India is the 'land of spices' and it is the largest producer, consumer and exporter of chillies in the world. Indian share in global production is 50 to 60 per cent. In India chilli occupies an area of 844 thousand hectares with an annual production of 2106 thousand metric tons (Spices Board of Indiawww.indianspices.com). The production of Chilli in India is dominated by Andhra Pradesh which occupies an area of 119 thousand ha with an annual production of 618 thousand t (Agricultural Statistics at GlanceA.P., 2017-18) which accounts for nearly 30 $\%$ to the total production. The major chilli growing districts in Andhra Pradesh are Guntur, Krishna and Prakasham. Guntur is the biggest chilli producing region with an area of 60 thousand ha and production of 351 thousand $t$ (Agricultural Statistics at a GlanceA.P., 2017-18) contributing 50\% to the total production of Andhra Pradesh. Area and production of Chilli in this area decides the prices at National level. Looking to the importance of this crop in the district the 
present study on resource use efficiency of dry chilli production was undertaken.

\section{Materials and Methods}

The data used in this study pertain to a sample of 99 chilli growers who belongs to 3 villages namely Sirigiripadu, Phanidam and Gummanampadu, from Veldurthi and Sattenapallii and Bollapalli mandals respectively of Guntur district, Andhra Pradesh. The Cobb-Douglas production function and profit functions were used for estimation of the resources use efficiency of chilli growers. Resource use efficiency can be defined as the ability to derive maximum output per unit of resource. Resource allocation and productivity is an important aspect to increase agricultural production, which is associated with the management of the farmers, who employ the resources in production. The Cobb-Douglas production function was used for the estimation of the resource use efficiency of inputs used in chilli production of different sizes of chilli growers. The Cobb-Douglas production function of following form is used:

$\mathrm{Y}=\mathrm{a} \mathrm{X}_{1}{ }^{\mathrm{b} 1} \mathrm{X}_{2}{ }^{\mathrm{b} 2} \mathrm{X}_{3}{ }^{\mathrm{b} 3} \mathrm{X}_{4}{ }^{\mathrm{b} 4} \mathrm{X}_{5}{ }^{\mathrm{b} 5} \mathrm{X}_{6}{ }^{\mathrm{b} 6} \mathrm{py}_{7}{ }^{\mathrm{b} 7}$

Where,

$\mathrm{Y}=$ Profit (Rs/farm) dependent variable

$\mathrm{X}_{1}=$ Price of seed $(\mathrm{Rs} / \mathrm{g})$

$\mathrm{X}_{2}=$ Prices of manure and fertilizer $(\mathrm{Rs} / \mathrm{t})$

$\mathrm{X}_{3}=$ Price of plant protection chemicals ( $\mathrm{Rs} / \mathrm{kg})$

$\mathrm{X}_{4}=$ Labour wages (Rs/person)

$\mathrm{X}_{5}=$ Bullock and machine labour wages (Rs/hr)

$\mathrm{X}_{6}=$ Fixed cost (Rs/farm)

$\mathrm{py}_{7}=$ Price of chilli (Rs/quintal)

$\mathrm{a}=$ Constant

$b_{1}$ to $b_{7}=$ Regression co-efficient of concerned variables
A profit (or cost) function relates maximized profits (or minimized costs) to the prices of product(s) and input(s), as also to the other exogenous variables such as fixed inputs, or agro-climatic and social variable. The parameters of a profit function contain all information about the underlying production function. The range of excessive usage of variable has been analyzed through a method called Profit function analysis. The profit function represents a particular factor prices to the maximum profit levels achievable at those output prices and factor prices. Mathematically it is denoted as following

$\pi=\pi(P, W)$

Where, Greek symbol $\pi$ denotes profit, $\mathrm{P}$ is a vector of output prices, $\mathrm{W}$ denotes vector of input prices.

$\pi(P, W)=A \pi_{i=1}^{n} P_{x i}^{-\alpha i} P_{y}^{\beta}$

Where, $\pi(P, W)$ is the profit from chilli enterprise, Pxi is the price of ith input $\mathrm{Py}$ is the price of chilli per quintal.

$\pi(P, W)=P y-\sum_{i=1}^{n} w x i-T F C$

Where,

Py is a gross income of farmer (Rs/farm)

Wxi is variable cost incurred for the production of chilli (Rs/farm)

TFC is total fixed cost incurred in production of chilli (Rs/farm)

After regression being run for Cobb-Douglass production function, resource use efficiency of inputs was calculated. According to theoretical considerations for Cobb-Douglass 
profit function, it is expected that coefficient price of input (variable) must be negative to find out the resource use efficiency of inputs. In the present investigation $\mathrm{X}_{5}$ (bullock and machine power) variable was found to be negatively significant. (P.L. Sankhayan, Introduction to the Economics of Agricultural production.)

$\frac{X i *}{X i}=\frac{\text { Optimum quantity of } i t \square \text { input }}{\text { Actual quantity of } i t \square \text { input }} X 100$

where, $x i^{*}$ is optimum quantity of $i^{\text {th }}$ variable and $x i$ is actual quantity of ith variable.

Optimum quantity of xi variable $\left(\mathrm{Xi}^{*}\right)$ :

$X i^{*}=-\beta \frac{\pi^{*}}{X i}$

Where, $\beta$ is coefficient of $i^{\text {th }}$ variable, $\pi^{*}$ is estimated level of profit from Cobb-Douglass profit function. First order partial derivation of profit function with respect to price of input provides negative of optimum quantity of input.

$\frac{-\partial \pi}{\partial \mathrm{pi}}=+X i$

\section{Estimated profit $\left(\pi^{*}\right)$}

Estimated profit was calculated by using following formula after $\log$ transformation of data on input and output.

$\pi^{*}=\ln \beta_{0}+\beta_{1} \ln X_{1}+\beta_{2} \ln X_{2}+\beta_{3} \ln X_{3}+\beta_{4} \ln X_{4}$

Where,

$\pi^{*}=$ Estimated profit (Rs/farm)

$\beta_{0}=$ Coefficient of intercept

$\beta_{1}-\beta_{7}=$ Coefficients of concerned variables

Other variables are same as specified for

Cobb-Douglas function.

\section{Results and Discussion}

The summary statistics of variables for the estimation of Cobb-Douglass production function are presented in the table 1 which shows that the average area under chilli was 2.99 ha per farm, average price of seed was Rs 34.92 per $\mathrm{g}$, the average cost of fertilizer and manure use was Rs 3758.39 per t, the average price of plant protection chemical was Rs 2150.02 per $\mathrm{kg}$, unit cost of labour was Rs 206.65per man, unit cost of machine power was Rs 319.36 per hr, average fixed cost was Rs 58114.14per farm, average price of dry chilli was Rs 7965.48 per quintal and mean of gross margin was Rs 879841.78per farm and standard deviation of Rs 586936.84 per farm. The larger variability in gross margin indicates that farmers cultivate different hectares of farmland under chilli crop with different proportion of input use.

The coefficients of different resources used are presented in table 2. According to the results from the data given in table the coefficient of multiple determination $\left(\mathrm{R}^{2}\right)$ was 0.96 it indicates that about 96 per cent of variations in the profit was explained by the model using explanatory variables $\left(\mathrm{X}_{1}\right.$ to $\left.\mathrm{Py}_{7}\right)$. The high values show the good representation of the relationship between farm profit and the included variables. The estimated coefficient for variables $X_{1}, X_{2}$ and $\mathrm{Py}_{7}$ i.e., seed, manures and fertilizers, and price of chilli, respectively are significantly different from zero at one per cent of significance. Plant protection chemical $\left(\mathrm{X}_{3}\right)$ is

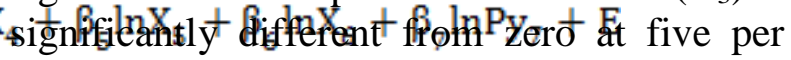
cent level of significance. Human labour wages $\left(\mathrm{X}_{4}\right)$ is not significant but positively influencing the profit. Machine labour wages $\left(\mathrm{X}_{5}\right)$ has significantly different from zero at one per cent level influencing the profit negatively and fixed cost $\left(\mathrm{X}_{6}\right)$ is not significant but positively influencing the profit. The analysis revealed that one percent 
increase in the price of chilli results in $1.99 \%$ increase in profit. One \% increase in machine labour results in $0.93 \%$ decrease in profit. (keeping other resources constant). Similar findings were also given by Thakare and Shende (2015).

Table.1 Summary statistics of variables for the estimation of Cobb-Douglass production function model for dry chilli production on sample Farms (N=99)

\begin{tabular}{|l|l|l|l|l|l|}
\hline S.No. & Variables & Minimum & Maximum & Mean & $\begin{array}{l}\text { Standard } \\
\text { deviation }\end{array}$ \\
\hline $\mathbf{1}$ & Farm size (ha) & 1.00 & 8.00 & 2.99 & 1.56 \\
\hline $\mathbf{2}$ & Average price of seed per gram & 33.10 & 39.00 & 34.92 & 1.08 \\
\hline $\mathbf{3}$ & Average price of fertilizer and manure per ton & 2984.55 & 4277.23 & 3758.39 & 252.26 \\
\hline $\mathbf{4}$ & $\begin{array}{l}\text { Average price of plant protection chemical per } \\
\text { kg }\end{array}$ & 1774.40 & 2474.89 & 2150.02 & 169.57 \\
\hline $\mathbf{5}$ & A unit cost of labour per man day & 197.00 & 221.68 & 206.65 & 5.23 \\
\hline $\mathbf{6}$ & A unit cost of machine power per hour & 279.74 & 406.36 & 319.36 & 18.57 \\
\hline $\mathbf{7}$ & Fixed cost per farm & 1800.00 & 192200.00 & 58114.14 & 46143.31 \\
\hline $\mathbf{8}$ & Average price per quintal & 6900.00 & 9222.17 & 7965.48 & 562.09 \\
\hline $\mathbf{9}$ & Gross margin per farm & 175364.18 & 3074950.00 & 879841.78 & 586936.84 \\
\hline
\end{tabular}

(In Rupees)

Table.2 Coefficients of Cobb-Douglass production function for dry chilli production on sample farms

\begin{tabular}{|c|c|c|}
\hline S.No & Variables & Coefficient \\
\hline 1 & Intercept & $\begin{array}{l}-81.839^{*} \\
(-18.337)\end{array}$ \\
\hline 2 & $\mathrm{X}_{1}$ Seed & $\begin{array}{l}18.806^{*} \\
(23.498)\end{array}$ \\
\hline 3 & $\mathrm{X}_{2}$ Manure and fertilizer & $\begin{array}{l}0.949^{*} \\
(3.948)\end{array}$ \\
\hline 4 & $\mathrm{X}_{3}$ Plant protection chemical & $\begin{array}{l}0.455^{* * *} \\
(2.396)\end{array}$ \\
\hline 5 & $\mathrm{X}_{4}$ Human labour & $\begin{array}{l}8.27 \\
(1.343)\end{array}$ \\
\hline 6 & $\mathrm{X}_{5}$ Bullock and Machine labour & $\begin{array}{l}-0.925^{*} \\
(-2.968)\end{array}$ \\
\hline 7 & $\mathrm{X}_{6}$ Fixed cost & $\begin{array}{l}0.022 \\
(1.520)\end{array}$ \\
\hline 8 & $\mathrm{Py}_{7}$ Price of chilli & $\begin{array}{l}1.992^{*} \\
(6.102)\end{array}$ \\
\hline 9 & $\begin{array}{l}\text { F statistical value } \\
\text { (F critical value) }\end{array}$ & $\begin{array}{l}313.006^{*} \\
(3.279)\end{array}$ \\
\hline 10 & $\mathrm{R}^{2}$ & 0.960 \\
\hline 11 & Adjusted $\mathrm{R}^{2}$ & 95.70 \\
\hline 12 & Number of observations (N) & 99 \\
\hline
\end{tabular}

*indicate significant at $1 \%$ level, $* *$ indicate significant at $5 \%$ level 
Table.3 Profit function analysis

\begin{tabular}{|l|l|l|}
\hline Particular & Actual value(Rs) & $\begin{array}{l}\text { Estimated } \\
\text { value(optimum Rs) }\end{array}$ \\
\hline Profit or Net income(per ha) & 193911.98 & 205539.98 \\
\hline Power use cost (per hr) & 322.76 & 119.34 \\
\hline Resource use efficiency & $=322.76 / 119.34 * 100=37 \%$ \\
\hline
\end{tabular}

Estimated profit and estimated $\mathrm{X}_{5}$ (power use) were calculated and presented in the table 3 . From the given data it can be concluded that chilli farmers are using excess amount of machine power $\left(\mathrm{X}_{5}\right)$ by $63 \%$, which equals Rs 204 per hr. Therefore the above analysis revealed that through optimization of power use on sample chilli farms the profitability would be increased by about six per cent but important point is that the cut in power use would save the fuel and will reduce the environmental pollution. These findings were confirmed by Nwachukwu and Onyenweaku (2009).

From profit function analysis we can conclude that chilli farmers are using excess amount of bullock and machine labour (power use) by $63 \%$ which equals to Rs. 204 per hr cut can be saved by efficient use of same by $37 \%$ thus the hypothesis of efficient resource use is rejected.

Thus optimization of these resources can save $37 \%$ energy use. Agriculture extension agencies should conduct the training programmes for chilli growers, so that inputs can be used more efficiently for reducing the cost and increasing the profit per unit area and per unit of input use.

\section{Acknowledgement}

I sincerely thank all professors of agricultural economics and farm management department, jawarlal Nehru krishi vishwa vidyalaya, Jabalpur, for their support and timely help. I extend my sincere thanks to the farmers of my study area for their generous response which made my research more reliable.

\section{References}

Agricultural Statistics at a Glance-A.P., 201718 Adeoye IB et al., (2014); Analysis of technical efficiency of pepper production among farmers under tropical conditions. International Journal of Vegetable Science 20(2):124130.

Ayodele OJ et al., (2016); Cost and benefit analysis of small holder pepper production. International Journal of Vegetable Sciences 22(4):402-408. https://www.tandfonline.com/doi/abs/10 $.1080 / 19315260.2015 .1137670$

Huq ASM and Arshad FM (2010), Technical Efficiency of Chili Production. American Journal of Applied Sciences 7 (2): 185-190.

Islam SM et al., (2011); Profitability and resource use efficiency of producing major spices in

Bangladesh. Bangladesh Journal of Agricultural Economics 34 (1\&2): 1-13. https://pdfs.semanticscholar.org/fc9f/a7 e9e3071c2301d464c5ddfa9d2eb13b250 1.pdf

Kale NKet al,. (2005); Resource use structure and efficiency in chilli cultivation in thane district of konkan region. Indian Journal of Agricultural Economics 60(3):529.

https://search.proquest.com/openview/fa 60b0615f3f57c46f07a2dc1e18955d/1?p q-origsite $=$ gscholar\&cbl $=46948$ 
Korikanthimath VS et al,. (2000); Resource productivities and their optimum utilization pattern in chilli based mixed cropping system-an economic analysis. Indian Journal of Horticulture 57(1):8386

http://www.indianjournals.com/ijor.asp $\mathrm{x}$ ?target=ijor:ijh\&volume $=57 \&$ issue $=1$ \&article $=018$

Mohammed B et al,. (2015); Profitability in chilli pepper production in Kaduna state, Nigeria. British Journal of Applied Science and Technology 12(3):1-9.

https://www.semanticscholar.org/paper/Profit ability-in-Chilli-Pepper-Production-inKaduna-MohammedAbdulsalam/50c65a2a656872707a68d6 58801994ee31b6ca83

Nwachukwu IF and Onyenweaku CE (2009), Economic efficiency of fadama telfairia https://mpra.ub.unimuenchen.de/13469/1/MPRA_paper_13 469.pdf

Patel JK et al,.(2014); An analysis of resource use efficiency of drip and conventional chilli farm in middle Gujarat. International Journal of Humanities and Social science.3(3):85-92.

https://scholar.google.com/scholar?hl=en\&as $\_$sdt $=0 \% 2 \mathrm{C} 5 \& \mathrm{q}=\mathrm{an}+$ analysis + of + resou rce+use+efficiency+of+drip+amd+conv entional+chiLi+cultivation \&btnG $=\# \mathrm{~d}=\mathrm{g}$ s_qabs\&u=\%23p\%3D_Wtbudg237wJ of Agricultural Production Shukla R (2010), Economics of chilli cultivation in Jaipur district of Rajasthan, International Journal of Commerce and Business Management, 3(1):267- 269. https://www.cabdirect.org/cabdirect/a bstract $/ 20113041278$

Spices Board of Indiawww.indianspices.com

Thakare SS and Shende NV (2015), Factor demand and output supply of paddy a normalized Cobb-Douglass profit function, Journal of Agricultural Economics and Rural Development, 3(7):310-316.

https://www.semanticscholar.org/paper/Factor -demand-and-output-supply-ofpaddy $\% 3 \mathrm{~A}-\mathrm{a}$-profitShende/57b207fdb80eef4c3dd22d2688f $617 \mathrm{a} 45530 \mathrm{~d} 173$

Tirlapur LN and Mundinamani SM (2015), Resource use efficiency in cultivation of major crops of Dharwad district, Agricultural Update, 10(2): 93-99. https://www.cabdirect.org/cabdirect/a bstract/20153265886

Wosor DK and Nimoh F (2012), Resource use efficiency in chilli production in the keta municipality of Volta region of Ghana, Elixir International Journal, 47(2012):8595-8598. https://www.elixirpublishers.com/article s/1350379464_47\%20(2012)\%2085958598.pdf

\section{How to cite this article:}

Ramana Kumari, Y. and Sunil Nahatkar. 2021. Resource Use Efficiency in Production of Dry Chilli in Guntur District of Andhra Pradesh, India. Int.J.Curr.Microbiol.App.Sci. 10(01): 33003305. doi: https://doi.org/10.20546/ijcmas.2021.1001.385 